Journal of Antimicrobial Chemotherapy (1992) 29, 41-48

\title{
Comparative in-vitro activity of new quinolones against clinical isolates and resistant mutants
}

\author{
P. Rohner, M. Peebo, D. P. Lew, R. Auckenthaler and J.-C. Pechère \\ University Hospital Geneva, Department of Infectious Diseases, \\ 24, Rue Micheli-du-Crest, CH-1211 Geneva 4, Switzerland
}

\begin{abstract}
The in-vitro activity of five new fuoroquinolones, WIN 57273, sparfloxacin, fleroxacin, temafloxacin and ciprofloxacin was determined against 543 recent clinical isolates and eight quinolone resistant strains derived by mutation and their five parent strains. WIN 57273 was the most active compound against Gram-positive bacteria, sparfloxacin had a broad spectrum which was similar to that of ciprofloxacin. Ciprofloxacin showed the greatest activity against Gram-negative bacteria. Temafioxacin showing some activity against Gram-positive organisms and Acinetobacter spp. Fleroxacin was the least active compound studied. Compared to wild type parent strains, the mutated strains produced the following results. In Enterobacter cloacae OmpF deficiency increased the MICs of all quinolones by 8-32-fold. In Pseudomonas aeruginosa OmpF deficiency had a limited effect, Omp D2 deficiency combined with an increased lipopolysaccharide content produced greater resistance, i.e. 4-16-fold; mutations in gyrase were associated with variously increased MICs, depending on the strain and compound tested.
\end{abstract}

\section{Introduction}

Many new quinolone antimicrobial agents have been described recently, some of which may reach clinical use. Ciprofloxacin is the most widely available quinolone with good activity against Gram-negative bacteria (Wolfson \& Hooper, 1989). The development of newer quinolones has aimed to produce compounds with better activity against Gram-positive and anaerobic bacteria (for example WIN 57273 and sparfloxacin) or improved pharmacokinetic properties (fleroxacin and temafloxacin). WIN 57273 [1-cyclopropyl-7-(2,6-di-methyl-4-pyridinyl)-6-fluoro-1,4-dihydro-4-oxo3-quinoline carboxylic acid] benefits from a 1-cyclopropyl group at position 7 of the quinolone ring and confers better activity against Gram-positive bacteria (Sedlock et al., 1990). Sparfloxacin (AT-4140 or RP 64206) [5-amino-1-cyclopropyl-6.8-difluoro-1.4-dihydro7(cis-3,5-dimethyl-1-piperazinyl)-4-oxoquinolone-3-carboxylic acid] is another new promising quinolone (Nakamura et al., 1989; Cooper et al., 1990).

The in-vitro activity of these new compounds has been compared to older quinolones and other antimicrobial agents (Paganoni et al., 1988; Nakamura et al., 1989; Cooper et al., 1990; Sedlock et al., 1990). In the present study we have directly compared ciprofloxacin to four newer quinolones using 543 recent clinical isolates to produce an indication of their relative merits in in-vitro tests. We also determined their activity against strains with known mechanisms of resistance to quinolones. 


\section{Materials and methods}

\section{Bacterial strains and antimicrobials used}

A total of 556 bacterial strains were studied of which 543 were recently isolated at the University Hospital of Geneva. The 21 isolates of Enterobacteriaceae (12 Escherichia coli, 7 Klebsiella pnewmoniae and 2 Enterobacter cloacae) resistant to nalidixic acid (MIC >16 mg/L) were evaluated separately. Eight strains in which the mechanism of resistance to quinolones have been described were also studied (Michea-Hampzehpour et al., 1987; Woodruff \& Hancock, 1988; Lucain et al., 1989; Michéa-Hampzehpour, Lucain \& Pechère, 1991). The five $E$. cloacae mutant strains were obtained from a murine model of peritonitis after pefloxacin treatment. They were characterized by outer membrane protein (Omp) $\mathrm{F}$ deficiency, as shown by outer membrane electrophoresis and by reduced uptake of $\left[{ }^{14} \mathrm{C}\right]$ pefloxacin. In addition to the altered permeability, partially purified DNA gyrase from three of the five strains showed a 100 - to 450-fold $50 \%$ inhibitory concentration increase of pefloxacin as determined by a supercoiling assay (Lucain et al., 1989). Pseudomonas aeruginosa H636 is a OmpF deficient mutant after in-vitro insertion mutagenesis of the cloned Omp F gene, kindly provided by W. A. Woodruff, Vancouver, Canada (Woodruff \& Hancock, 1988). $P$. aeruginosa 305 PT1 and PT2 were obtained in mice after pefloxacin therapy (Michéa-Hampzehpour et al., 1991). The post-therapy isolate PTl was characterized by the absence of Omp D2 on Western (immuno) blotting, decreased [ $\left.{ }^{14} \mathrm{C}\right]$ pefloxacin uptake, altered lipopolysaccharide pattern and increased 3-deoxy-D-mannooctulosonic acid (KDO) concentration in the outer membrane. The post-therapy strain PT2 had an unchanged outer membrane but displayed altered DNA gyrase, determined indirectly by pefloxacin inhibition of the $\left[2-{ }^{3} \mathrm{H}\right]$ adenine incorporation.

Laboratory standards with known potency of the antimicrobials used were supplied as follows: WIN 57273 by Sterling Drug Inc. USA, sparfloxacin by Rhône-Poulenc Santé, France, fleroxacin by Hoffman-La Roche, Switzerland, temafloxacin by Abbott, USA and ciprofloxacin by Bayer AG, Germany.

\section{Susceptibility tests}

Minimum inhibitory concentrations (MICs) of the five compounds were determined by an agar-dilution method (National Committee for Clinical Laboratory Standards, 1990). The medium used was Mueller-Hinton agar (Oxoid, Basingstoke, UK), but for testing Proteeae 1.3\% agar was added and for fastidious organisms it was supplemented with $5 \%$ lysed horse blood and Isovitalex at the manufacturers recommended concentration (Bio-Mérieux, France). A multipoint-inoculator (Cathra systems, MCT Medical, Minnesota, USA) delivering $1 \mu \mathrm{L}$ per spot was used to inoculate these plates with $10^{\circ} \mathrm{cfu}$. All plates were incubated at $35^{\circ} \mathrm{C}$ for $18-20 \mathrm{~h}$. An incubation atmosphere of air with $5 \% \mathrm{CO}_{2}$ was used for Haemophilus spp. and Neisseria spp. The MIC was determined as the lowest concentration of an agent which completely inhibited growth disregarding a single colony or a faint haze of growth.

\section{Results}

The comparative activity of the five quinolone agents against 543 recent clinical isolates is shown in Table I. Ciprofloxacin was the most active agent against Gram-negative 
Table I. Comparative MICs of five quinolone agents for recent clinical isolates of bacteria, the number of isolates tested is shown in parentheses

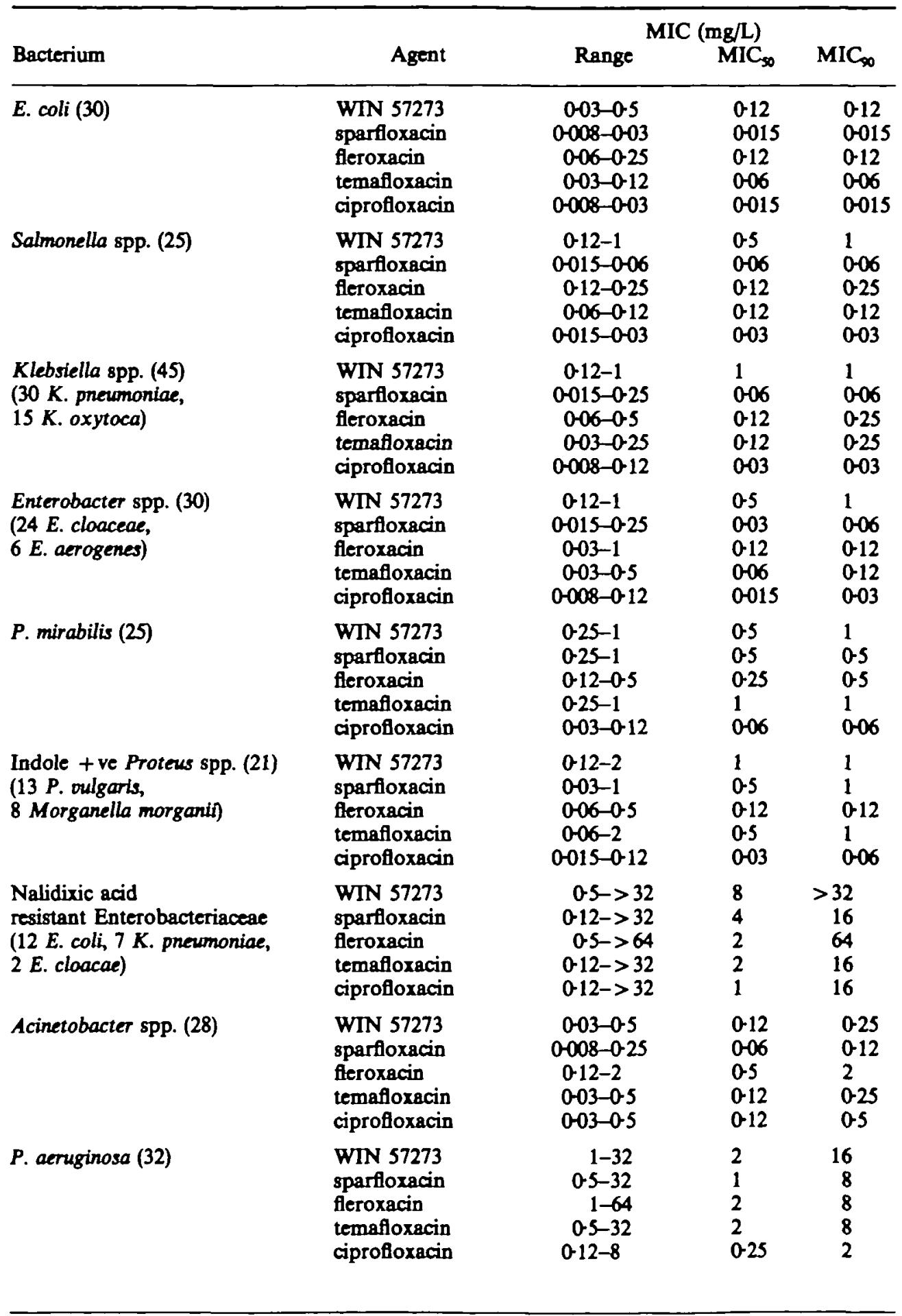


Table I-continued

\begin{tabular}{|c|c|c|c|c|}
\hline Bacterium & Agent & Range & $\frac{\mathrm{ng} / \mathrm{L})}{\mathrm{MIC}}$ & $\mathrm{MIC}_{90}$ \\
\hline$X$. maltophilia (14) & $\begin{array}{l}\text { WIN } 57273 \\
\text { sparfloxacin } \\
\text { fleroxacin } \\
\text { temafloxacin } \\
\text { ciprofloxacin }\end{array}$ & $\begin{array}{c}0-5-4 \\
0-25-2 \\
2-16 \\
0-5-8 \\
1-16\end{array}$ & $\begin{array}{l}1 \\
1 \\
4 \\
4 \\
2\end{array}$ & $\begin{array}{l}4 \\
1 \\
8 \\
8 \\
8\end{array}$ \\
\hline H. influenzae (26) & $\begin{array}{l}\text { WIN } 57273 \\
\text { sparfloxacin } \\
\text { fleroxacin } \\
\text { temafloxacin } \\
\text { ciprofloxacin }\end{array}$ & $\begin{array}{c}\leqslant 0-004-0-008 \\
\leqslant 0-004-0-008 \\
0-015-0-06 \\
0-008-0-12 \\
0-008-0-03\end{array}$ & $\begin{array}{l}\leqslant 0-004 \\
\leqslant 0-004 \\
0-06 \\
0-015 \\
0-015\end{array}$ & $\begin{array}{c}\leqslant 0-004 \\
\leqslant 0-004 \\
0-06 \\
0-06 \\
0-03\end{array}$ \\
\hline Neisseria meningitidis (29) & $\begin{array}{l}\text { WIN } 57273 \\
\text { sparfoxacin } \\
\text { fleroxacin } \\
\text { temafloxacin } \\
\text { ciprofloxacin }\end{array}$ & $\begin{array}{c}\leqslant 0-004-0-008 \\
\leqslant 0-004-0-008 \\
0-03 \\
0-008-0-03 \\
\leqslant 0-004-0-008\end{array}$ & $\begin{array}{c}\leqslant 0-004 \\
\leqslant 0-004 \\
0-03 \\
0-015 \\
\leqslant 0-004\end{array}$ & $\begin{array}{c}\leqslant 0-004 \\
0-008 \\
0-03 \\
0-015 \\
\leqslant 0-004\end{array}$ \\
\hline Moraxella catarthalis (17) & $\begin{array}{l}\text { WIN } 57273 \\
\text { sparfloxacin } \\
\text { fleroxacin } \\
\text { temafloxacin } \\
\text { ciprofloxacin }\end{array}$ & $\begin{array}{l}0-008-0-03 \\
0-015-0-03 \\
0-25 \\
0-06-0-12 \\
0-03-0-06\end{array}$ & $\begin{array}{l}0-015 \\
0-03 \\
0-25 \\
0-06 \\
0-06\end{array}$ & $\begin{array}{l}0-015 \\
0-03 \\
0-25 \\
0-12 \\
0-06\end{array}$ \\
\hline $\begin{array}{l}\text { Methicillin-susceptible } \\
\text { S. aureus (20) }\end{array}$ & $\begin{array}{l}\text { WIN } 57273 \\
\text { sparfloxacin } \\
\text { fleroxacin } \\
\text { temafloxacin } \\
\text { ciprofloxacin }\end{array}$ & $\begin{array}{c}50-008-0.015 \\
0-015-0-06 \\
0-25-0.5 \\
0-12-0-25 \\
0-06-0.5\end{array}$ & $\begin{array}{c}\leqslant 0-008 \\
0.03 \\
0-5 \\
0.25 \\
0.25\end{array}$ & $\begin{array}{l}0-015 \\
0-06 \\
0-5 \\
0.25 \\
0-25\end{array}$ \\
\hline $\begin{array}{l}\text { Methicillin-resistant } \\
\text { S. aureus (21) }\end{array}$ & $\begin{array}{l}\text { WIN } 57273 \\
\text { sparfloxacin } \\
\text { fleroxacin } \\
\text { temafloxacin } \\
\text { ciprofloxacin }\end{array}$ & $\begin{array}{c}50-008-0-015 \\
0-015-0-12 \\
0-5-1 \\
0.25-0.5 \\
0.12-0.5\end{array}$ & $\begin{array}{c}<0-008 \\
0-03 \\
0.5 \\
0-25 \\
0-25\end{array}$ & $\begin{array}{l}<0-008 \\
0-06 \\
0-5 \\
0-25 \\
0-5\end{array}$ \\
\hline $\begin{array}{l}\text { Coagulase-negative } \\
\text { Staphylococcus spp. (21) }\end{array}$ & $\begin{array}{l}\text { WIN } 57273 \\
\text { sparfloxacin } \\
\text { fleroxacin } \\
\text { temafloxacin } \\
\text { ciprofloxacin }\end{array}$ & $\begin{array}{c}<0-008-0-03 \\
0-06-0-25 \\
0-5-8 \\
0-25-2 \\
0-06-1\end{array}$ & $\begin{array}{l}60.008 \\
0.12 \\
0.5 \\
0.12 \\
0.12\end{array}$ & $\begin{array}{l}0-015 \\
0-12 \\
1 \\
0-25 \\
0-12\end{array}$ \\
\hline S. pyogenes (22) & $\begin{array}{l}\text { WIN } 57273 \\
\text { sparfloxacin } \\
\text { fleroxacin } \\
\text { temafloxacin } \\
\text { ciprofloxacin }\end{array}$ & $\begin{array}{c}0-06-0.25 \\
0.25-0.5 \\
2-16 \\
1-4 \\
0.25-1\end{array}$ & $\begin{array}{l}0.12 \\
0.5 \\
8 \\
1 \\
1\end{array}$ & $\begin{array}{l}0.25 \\
0.5 \\
16 \\
2 \\
1\end{array}$ \\
\hline S. agalactiae (22) & $\begin{array}{l}\text { WIN } 57273 \\
\text { sparfloxacin } \\
\text { fleroxacin } \\
\text { temafloxacin } \\
\text { ciprofloxacin }\end{array}$ & $\begin{array}{c}0-12-0.25 \\
0-25-0.5 \\
1-16 \\
0.5-2 \\
0.5-2\end{array}$ & $\begin{array}{l}0-12 \\
0-5 \\
8 \\
1 \\
1\end{array}$ & $\begin{array}{l}0.12 \\
0-5 \\
8 \\
1 \\
1\end{array}$ \\
\hline
\end{tabular}


Table I.-continued

\begin{tabular}{|c|c|c|c|c|}
\hline Bacterium & Agent & Range & $\mathrm{MIC}_{\mathrm{so}}$ & $\mathrm{MIC}_{\boldsymbol{x}}$ \\
\hline S. prewmoniae (22) & $\begin{array}{l}\text { WIN } 57273 \\
\text { sparfloxacin } \\
\text { fleroxacin } \\
\text { temafloxacin } \\
\text { ciprofloxacin }\end{array}$ & $\begin{array}{c}0-03-0-12 \\
0-06-0.5 \\
1-16 \\
0-5-4 \\
0.5-2\end{array}$ & $\begin{array}{l}0-06 \\
0-25 \\
4 \\
1 \\
1\end{array}$ & $\begin{array}{l}0.06 \\
0.25 \\
8 \\
2 \\
2\end{array}$ \\
\hline E. faecalis (28) & $\begin{array}{l}\text { WIN } 57273 \\
\text { sparfloxacin } \\
\text { fleroxacin } \\
\text { temafloxacin } \\
\text { ciprofloxacin }\end{array}$ & $\begin{array}{c}0-03-8 \\
0-25-4 \\
2-16 \\
0-5-8 \\
0-25-8\end{array}$ & $\begin{array}{l}0.12 \\
0.5 \\
8 \\
2 \\
1\end{array}$ & $\begin{array}{l}2 \\
2 \\
8 \\
4 \\
4\end{array}$ \\
\hline E. faecium (22) & $\begin{array}{l}\text { WIN } 57273 \\
\text { sparfloxacin } \\
\text { fleroxacin } \\
\text { temafloxacin } \\
\text { ciprofloxacin }\end{array}$ & $\begin{array}{c}0-12-8 \\
0-5-4 \\
4-16 \\
1-16 \\
1-8\end{array}$ & $\begin{array}{l}4 \\
2 \\
8 \\
4 \\
4\end{array}$ & $\begin{array}{r}8 \\
4 \\
16 \\
8 \\
4\end{array}$ \\
\hline L. manocytogenes (22) & $\begin{array}{l}\text { WIN } 57273 \\
\text { sparfloxacin } \\
\text { fleroxacin } \\
\text { temafloxacin } \\
\text { ciprofloxacin }\end{array}$ & $\begin{array}{c}0.12-0.25 \\
1-2 \\
2-16 \\
0-5-8 \\
0-5-2\end{array}$ & $\begin{array}{l}0-12 \\
2 \\
8 \\
2 \\
1\end{array}$ & $\begin{array}{l}0-25 \\
2 \\
8 \\
2 \\
1\end{array}$ \\
\hline
\end{tabular}

bacteria, with the exception of Acinetobacter spp. and Xanthomonas maltophilia when sparfloxacin was more active and Moraxella catarrhalis when WIN 57273 was four-fold and sparfloxacin was two-fold more active than ciprofloxacin. Against Enterobacteriaceae, (excluding Proteus spp.), a one- to four-fold increase in activity was noted, the agents in order of increasing activity being WIN 57273, fleroxacin, temafloxacin, sparfloxacin and ciprofloxacin. When a group of 21 nalidixic acid resistant isolates of Enterobacteriaceae were examined, a similar increase in MIC was observed for all the quinolones tested compared to the nalidixic acid sensitive species $\left(2^{4}\right.$-to $2^{10}$-fold increased MIC $_{s 0}$ or MIC $\left._{90}\right)$. All the agents tested with the exception of ciprofloxacin, showed poor activity against Proteus mirabilis. Ciprofloxacin and fleroxacin were the most active against the indole positive Proteus spp. being $\geqslant 4$-fold more active than the other agents.

The most active compound against Gram-positive bacteria was WIN 57273 followed by sparfloxacin, ciprofloxacin, temafloxacin and fleroxacin. Interestingly sparfloxacin was twice as active against Staphylococcus aureus than coagulase-negative Staphylococcus spp. in contrast to ciprofloxacin which was 2 times less active in this context. Against Streptococcus spp. and Enterococcus spp. good activity for WIN 57273 and sparfloxacin was observed, but relatively high MICs of fleroxacin, temafloxacin and ciprofloxacin were noted. All the quinolones tested had poor activity against Enterococcus faecium; against Listeria monocytogenes only WIN 57273 had good activity.

Table II shows the activity of quinolones against various mutants with known mechanisms of resistance to quinolones. OmpF deficiency in E. cloacae was associated 
Table II. MICs of WIN 57273 (WIN), sparfloxacin (SPX), fleroxacin (FLX), temafloxacin (TEM) and ciprofloxacin (CIP) for bacterial strains with known mechanisms of resistance and MIC increase in $191 \mathrm{C}$ compared to the parent strain

\begin{tabular}{|c|c|c|c|c|c|c|c|c|c|c|}
\hline \multirow[b]{2}{*}{ Strain (alteration) } & \multicolumn{5}{|c|}{$\operatorname{MIC}(\mathrm{mg} / \mathrm{L})$} & \multicolumn{5}{|c|}{ MIC increase } \\
\hline & WIN & SPX & FLX & TEM & CIP & WIN & SPX & FLX & TEM & CIP \\
\hline $\begin{array}{l}\text { E. cloacae } 218 \text { PT1 } \\
\text { (OmpF deficient) }\end{array}$ & 4 & 1 & 1 & 2 & 0.25 & $2^{3}$ & $2^{3}$ & $2^{3}$ & $2^{4}$ & $2^{4}$ \\
\hline $\begin{array}{l}\text { E. cloacae } 908 \text { PT1 } \\
\text { (OmpF deficient) }\end{array}$ & 2 & 1 & 1 & 1 & $0-25$ & $2^{3}$ & $2^{5}$ & $2^{3}$ & $2^{3}$ & $2^{4}$ \\
\hline $\begin{array}{l}\text { E. cloacae } 218 \text { PT } \\
\text { (OmpF deficient }+ \text { gyr) }\end{array}$ & 32 & 8 & 32 & 16 & 8 & $2^{6}$ & $2^{6}$ & $2^{3}$ & $2^{7}$ & 29 \\
\hline $\begin{array}{l}\text { E. cloacae } 219 \text { PT } 1 \\
\text { (OmpF deficient }+\mathrm{gyr})\end{array}$ & 16 & 1 & 4 & 4 & 0.5 & $2^{6}$ & $2^{3}$ & $2^{4}$ & $2^{3}$ & $2^{5}$ \\
\hline $\begin{array}{l}\text { E. cloacae } 908 \mathrm{PT} 2 \\
\text { (OmpF deficient + gyr) }\end{array}$ & 64 & 8 & 16 & 16 & 2 & $2^{2}$ & $2^{2}$ & $2^{7}$ & $2^{7}$ & $2^{7}$ \\
\hline $\begin{array}{l}P \text {. aeruginosa H } 636 \\
\text { (OmpF deficient) }\end{array}$ & 16 & 2 & 4 & 4 & 1 & $2^{2}$ & $2^{0}$ & $2^{1}$ & $2^{0}$ & $2^{\circ}$ \\
\hline $\begin{array}{l}\text { P. aeruginosa } 305 \text { PT1 } \\
\left.\text { (Perm }{ }^{b}\right)\end{array}$ & 16 & 16 & 8 & 8 & 2 & $2^{3}$ & $2^{2}$ & $2^{2}$ & $2^{2}$ & $2^{4}$ \\
\hline $\begin{array}{l}P . \text { aeruginasa } 305 \mathrm{PT} 2 \\
(\mathrm{gyT})\end{array}$ & 16 & 4 & 8 & 4 & 0.5 & $2^{3}$ & $2^{0}$ & $2^{2}$ & $2^{1}$ & $2^{2}$ \\
\hline
\end{tabular}

-Altered DNA gyrase.

'Altered permeability due to the combination of decreased expression of OmP D2 and increased production of lipopolysaccharides.

with an 8- to 32-fold increase in MICs with parallel changes seen with all the compounds. The OmpF deficient mutants which also possessed an altered DNA gyrase showed variation in susceptibility to quinolones from strain to strain. The strains of E. cloacae $219 \mathrm{PT} 1$ and $908 \mathrm{PT} 2$ were more susceptible to ciprofloxacin than WIN 57273; the opposite was noticed for strain E. cloacae 218 PT2. In strains of $P$. aeruginosa, OmpF deficiency had a limited effect on quinolone activity. Altered permeability due to the combination of decreased expression of Omp D2 and increased production of lipo-polysaccharide influence the activity of all quinolones by 4 to $16-$ fold changes in MIC. Alteration of the $P$. aeruginosa gyrase produced effects depending on the agent, sparfloxacin showing no changes whereas WIN 57273 showed an eightfold increase in MIC.

\section{Discussion}

In this study we confirm that the development of new quinolones like sparfloxacin or WIN 57273 has lead to an increased activity against Gram-positive bacteria when compared to older agents. Our results, in which we made direct comparison of five recently developed quinolones, are similar to those published by other investigators in a different setting (Auckenthaler et al., 1986; Paganoni et al., 1988; Nakamura et al., 1989; Cooper et al., 1990; Sedlock et al., 1990). WIN 57273 showed good activity against Gram-positive bacteria, with the exception of E. faecium. Depending on its pharmacological properties and toxicological profile, WIN 57273 could become a useful agent to treat infections caused by Staphylococcus spp., Streptococcus spp. and L. monocytogenes. 
Sparfloxacin was less active against Gram-positive bacteria than WIN 57273, but it had a broader spectrum of activity, more like ciprofloxacin. The two- to four-fold decrease in MIC of sparfloxacin compared to ciprofloxacin for Streptococcus pneumoniae could be an advantage in the treatment of community acquired respiratory infections. The in-vitro activity of temafloxacin was interesting against quinolone susceptible Gram-positive bacteria. Fleroxacin was the least active compound, but these results should be interpreted in relation to its distinctive pharmacokinetic properties. Comparing the results for ciprofloxacin to those we obtained in a study we conducted five years ago (Auckenthaler et al., 1986), we noted similar MICs, even though a completely different set of strains was tested. Only the $\mathbf{M I C}_{\mathbf{s}_{0}}$ for Salmonella spp. and $P$. mirabilis and the $\mathrm{MIC}_{90}$ for $P$. aeruginosa, Haemophilus influenzae and $E$. faecalis have increased four-fold, but that for Acinetobacter spp. has decreased by a factor of 4.

As the nalidixic acid resistance rate for Enterobacteriaceae is lower than $5 \%$ in our hospital, we separately listed a selection of these strains. The overall MIC values were similarly increased for all quinolones compared to nalidixic acid susceptible Enterobacteriaceae. However, differences for individual strains were noted.

In Gram-negative bacilli two mechanisms of quinolone resistance have been recognized affecting the penetration through the outer membrane or the affinity to the target molecule, DNA gyrase. Permeability mutants in E. cloacae are characterized by altered outer membrane protein patterns, principally marked by a decreased $37 \mathrm{kDa}$ band (named OmpF in analogy to $E$. coli) accompanied by an increased $42 \mathrm{kDa}$ band (i.e. OmpC) (Lucain et al., 1989). In our study, strains possessing these changes showed a moderate increase in resistance to all five agents. In order to evaluate the impact of alteration of the DNA gyrase, as no strain only carrying a gyrase mutation was available to us, we tested three strains having an altered gyrase combined with a decreased permeability. These strains with two mechanisms of resistance showed marked resistance to the quinolones tested. Furthermore we observed that MICs of these quinolones were not equally altered. For two strains WIN 57273 was more affected than ciprofloxacin, the opposite applied for the third strain. This opposite trend remained also when subtracting the theoretical contribution of reduced permeability. This suggests that various mutations of the DNA gyrase have different effects on quinolone activity as has been shown in S. aureus (Hopewell et al., 1990).

Changes in the outer membrane of $P$. aeruginosa with altered permeability are complex, with modified protein and lipopolysaccharide band patterns (MichtaHamzehpour et al., 1991). When we tested the OmpF deficient strain of $P$. aeruginosa H 636, we observed only small changes in MIC. The role of Protein F as a porin in $P$. aeruginosa has been controversial (Gotoh et al., 1989; Woodruff et al., 1988), but it has been recently reported that it may function as a major non-specific porin for the diffusion of hydrophilic solutes with limited permeability (Nikaido, Nikaido \& Harayama, 1991). According to our observations, the role of OmpF in quinolone resistance remains doubtful. However, the contribution of this porin in quinolone uptake cannot be definitely ruled out because the structure of the outer membrane is greatly altered in OmpF deficient mutants (Woodruff et al., 1988). We also tested a strain of $P$. aeruginosa with altered permeability due to reduced expression of Omp D2 combined with increased amount of lipopolysaccharides in the outer membrane. These alterations more markedly reduced the activity of quinolones than did deficiency of OmpF, which confirms our recent observation that both Omp D2 and 
lipo-polysaccharides are involved in the diffusion of quinolones through the outer membrane (Michéa-Hamzehpour et al., 1991). Interestingly, we observed that in a $P$. aeruginosa strain with only a mutated DNA gyrase, similar changes in the MICs of quinolones were seen as observed for $E$. cloacae.

\section{Acknowledgements}

This work was supported by the Fonds National Suisse de la Recherche Scientifique (grant numbers 31-28007.89 and 32-30161.90). We thank Ivana Ratti and Vivianne Dunand for the technical work, Robert E. W. Hancock for providing two $P$. aeruginosa strains and Mehri Michéa-Hamzehpour for valuable advice in writing the manuscript. Some of these results have been presented at the 3rd International Symposium on New Quinolones, Vancouver, 12-14 July 1990, abstract no. 41.

\section{References}

Auckenthaler, R., Michér-Hamzehpour, M. \& Pechère, J.-C. (1986). In-vitro activity of newer quinolones against aerobic bacteria. Journal of Antimicrobial Chemotherapy 17, Suppl. B, 29-39.

Cooper, N. A., Andrews, J. M., Ashby, J. P., Matthews, R. S. \& Wise, R. (1990). In-vitro activity of sparfloxacin, a new quinolone antimicrobial agent. Journal of Antimicrobial Chemotherapy 26, 667-76.

Gotoh, N., Wakebe, H., Yoshihara, E., Nakae, T. \& Nishino, T. (1989). Role of protein F in maintaining structural integrity of the Pseudomonas aeruginosa outer membrane. Journal of Bacteriology 171, 983-90.

Hopewell, R., Oram, M., Briesewitz, R. \& Fisher, L. M. (1990). DNA cloning and organization of the Staphylococcus aureus gyr $A$ and gyr $B$ genes: close homology among gyrase proteins and implications for 4-quinolone action and resistance. Journal of Bacteriology 172, 3481-4.

Lucain, C., Regamey, P., Bellido, F. \& Pechère, J.-C. (1989). Resistance emerging after pefloxacin therapy of experimental Enterobacter cloacae peritonitis. Antimicrobial Agents and Chemotherapy 33, 937-43.

Michta-Hamzehpour, M., Auckenthaler, R., Regamey, P. \& Pechère, J.-C. (1987). Resistance occurring after fluoroquinolone therapy of experimental Pseudomonas aeruginosa peritonitis. Antimicrobial Agents and Chemotherapy 31, 1803-8.

Michéa-Hamzehpour, M., Lucain, C. \& Pechère, J.-C. (1991). Resistance to pefloxacin in Pseudomonas aeruginosa. Antimicrobial Agents and Chemotherapy 35, 512-8.

Nakamura, S., Minami, A., Nakata, K., Kurobe, N., Kuono, K., Sakaguchi, Y. et al. (1989). In vitro and in vivo antibacterial activities of $\mathrm{AT}-4140$, a new broad-spectrum quinolone. Antimicrobial Agents and Chemotherapy 33, 1167-73.

National Committee for Clinical Laboratory Standards. (1990). Methods for Dilution Antimicrobial Susceptibility Tests for Bacteria that Grow Aerobically, 2nd edn; Approved Standard $M 7-A Z$, NCCLS, Villanova, PA.

Nikaido, H., Nikaido, K. \& Harayama, S. (1991). Identification and characterization of porins in Pseudomonas aeruginosa. Journal of Biological Chemistry 266, 770-9.

Paganoni, R., Herzog, C., Braunsteiner, A. \& Hohl, P. (1988). Fleroxacin: in-vitro activity worldwide against 20,807 clinical isolates and comparison to ciprofloxacin and norfloxacin. Journal of Antimicrobial Chemotherapy 22, Suppl. D., 3-17.

Sedlock, D. M., Dobson, R. A., Deuel, D. M., Lesher, G. Y. \& Rake, J. B. (1990). In vitro and in vivo activities of a new quinolone, WIN 57273, possessing potent activity against Gram-positive bacteria. Antimicrobial Agents and Chemotherapy 34, 568-75.

Wolfson, J. S. \& Hooper, D. C. (1989). Fluoroquinolone antimicrobial agents. Clinical Microbiology Reviews 2, 378-424.

Woodruff, W. A. \& Hancock, R. E. W. (1988). Construction and characterization of Pseudomonas aeruginosa protein F-deficient mutants after in vitro and in vivo insertion mutagenesis of the cloned gene. Journal of Bacteriology 170, 2592-8.

(Received 8 March 1991; revised version accepted 4 September 1991) 